\title{
An Analysis of Newspaper Depictions of Schooling: a Participatory Study for the Development of a Teacher Education Curriculum
}

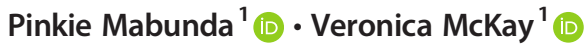 \\ Accepted: 11 October 2020 / Published online: 3 November 2020 \\ C) Springer Science+Business Media, LLC, part of Springer Nature 2020
}

\begin{abstract}
Many researchers argue that the news media play a significant role in the education policy arena, influencing the way in which issues are prioritized and understood. This article draws on a content analysis of the South African English news media articles over 21 months (October 2018-June 2020) to discern themes that were prioritized and given prominence and to explore the way in which these themes might present additional insights for framing the curriculum for initial teacher education programmes. We engaged with articles about basic education that were on the Government Communications and Information System site during this period and analysed those that we considered significant for the context or situational components in teacher education. We selected a final subset of 360 news articles that related to contextual aspects in schooling and we analysed the content of these articles. The analysis is regarded as being participatory in the sense that we engaged with the voices of civil society articulated via the mass media. Our engagement with the media was considered action oriented for purposes of informing curriculum design, with the media being a significant realm of social life through which public opinion can both be formed and, through the participation of citizens, used as a vehicle to have an impact on the political expressions by citizens who have information they would like to share. In this sense, the public and advocacy organisations can use the media as a watchdog to protect public interests against malpractice and to create public awareness about issues of societal importance.
\end{abstract}

Keywords Participatory action research $\cdot$ Content analysis $\cdot$ News media $\cdot$ Curriculum development $\cdot$ Teacher education $\cdot$ Situational knowledge $\cdot$ COVID-19

Pinkie Mabunda

Mabunpl@unisa.ac.za

Veronica McKay

Mckayvi@unisa.ac.za

1 College of Education, University of South Africa, Pretoria, South Africa 


\section{Background}

An emerging field of education research focuses on public discourse about education issues, in and through the social as well as the traditional print media such as newspapers which influence and shape education news and information, enabling a better understanding and enhancing the engagement of education stakeholders (Baroutsis 2019:6-7). A growing body of education research explored print media representations of different aspects of education arguing that the print media can shape and reflect dominant perceptions of education in various contexts (Mockler 2018).

Similarly, Coe and Kuttner (2018:1) point out that the news media play a significant role in the education policy arena, influencing the way in which issues are prioritized and understood. They indicate that researchers need to consider "how much attention news media give to education, which topics are covered, and how topics are addressed. .. [and also to analyse the] growing body of research through a quantitative content analysis".

Whereas Coe and Kuttner (2018) regard "quantitative" content as the preferred approach, this study argues for an active engagement in the content analysis as one of the elements to guide action-oriented curriculum development. Following Kemmis (2009:468), our engagement with the news media follows the practice of action research involving what "happens in sayings, doings and relatings" with, as Kemmis posits, "relatings" involved in the "relationships between speakers and hearers, authors and readers and those observing the debates about it". Through our engagement with the "voices" in the media articles, and through our coreflecting on these, we were able to explore alternatives and reflect on possibilities which were valuable in informing the new curriculum. ${ }^{1}$

\section{The Media and the Context of Schooling}

We contend in this article that many of the themes raised by the media gave rise to policy deliberations and impact on policymaking. ${ }^{2}$ We considered that the identification of themes and topics given prominence as offering a contextual or situational backdrop to be considered in teacher education curricula when identifying areas of focus for the teaching of situational learning which is described in the minimum requirements for teacher education qualifications (MRTEQ), (DHET (Department of Higher Education and Training) 2015:11) as the:

knowledge of the varied learning situations, contexts and environments of education (classrooms, schools, communities, districts, regions, countries and globally). .. the prevailing policy, political and organisational contexts and includes an understanding of the complex and differentiated nature of the South African society, learning to work in nuanced ways in confronting the diverse challenges faced by children in schools and the communities they serve, for example HIV and AIDS, poverty and the lingering effects of apartheid, dealing with diversity, promoting inclusivity and environmental sustainability.

\footnotetext{
${ }^{1}$ The use of action research approaches in curriculum development have been well documented (Liu and Lin 2017; Tsai and Liu 2019).

${ }^{2}$ Examples of such policies relate to school safety, particularly in relation to safety in the COVID-19 pandemic, to the conceptualization of education recovery programmes, and to deliberations by the South African Council for Educators over the renewal of teachers' professional registration and the provision of police clearances.
} 
The MRTEQ policy for teacher education qualifications promotes the integration of various types of knowledge, namely, disciplinary learning, pedagogical learning, practical learning, fundamental learning and situational learning that should underpin teachers' practice. Teachers should draw on this practical and theoretical knowledge mix to "guide their decisions in the moment of practice" (Luckay 2018). Each of these knowledge areas is important to develop a conceptually coherent and contextually responsive teacher. In her analysis of the underpinning knowledge promoted in the MRTEQ, Rusznyak (2015:4) explains that ITE curricula should include:

specified proportions of disciplinary learning (which includes educational theoretical knowledge, as well as subject content knowledge and its associated skills), pedagogical learning (including general pedagogical knowledge and pedagogical content knowledge), practical learning (knowledge acquired from observing, analysing and reflecting on one's own teaching and the teaching of others), situational learning (learning about the diverse contexts in which education exists) and foundational learning (the generic knowledge and competences that are not teacher-specific, but might be useful in the dayto-day work that teachers do).

While Rusznyak (2015) elaborates on the importance of the integration of these four knowledge types, she argues that the context or situation becomes relevant whenever the other types of knowledge are foregrounded. In this article, we focus specifically on the context or situation of education as has been depicted via the representations of the printed news media as being relevant to teacher education.

\section{Media Analysis as an Action-Oriented Enterprise}

As we indicated above, the influence of the news media transcends simply informing the public about issues. Coe and Kuttner (2018:2) argue, the news media has the potential to define the kinds of issue focused on and the way in which they are dealt with, because their influence goes deeper than simply informing the public about important issues and acting as a voice of civil society particularly with regard to social issues in education. As they point out, the media has the potential to identify problems of schooling and to set the agenda for redressing them in policy and practice. For this reason, they argue that an analysis of the news media is an important component of education research, policy and practice.

While we do not underestimate the role of the reader as an active participant in the interpretation of media messages, we are cognizant of the potential of the media in setting the agenda, guiding policy formulation and highlighting a number of critical contextual and situational aspects that frame schooling. It is for this reason, that we regard the analysis as being participatory in articulating the voice of civil society which finds expression through the media and gives rise to actions in education policy and practice. Rheingold $(2008: 101)$ in fact refers to the media as the realm of social life in the public sphere where, through the participation of citizens, the media can act as a vehicle that has an impact on the political expressions. Drawing on the work of Jurgen Habermas, he regards the public sphere as a democratic system open to any citizen who has information they would like to share with society through all channels of communications. 
Rheingold (2008) argues that media democracy entails a "more equal distribution of economic, social, cultural, and information capital, which would lead to a more informed citizenry, as well as a more enlightened, representative political discourse". It provides possibilities to "advocate positions, contest claims, and organize action around issues" (Rheingold 2008:102). Habermas (1974) defined the public sphere as a vehicle for political expression, drawing attention to the intimate connection between a web of free, informal personal communications and the foundations of a democratic society.

In this sense, the Habermasian emancipatory interest, with knowledge being constituted as discursive and dialogical and guided by reflection, is action oriented (McKay 2018a). As McKay and Romm (2008:153) argue, "active action" research enables decision makers to become more attuned to public considerations to provide opportunities for systemic changes. Following this argument, the reflection on the media gives rise to praxis which, as McKay (2018a) explains, is derived from "reflection + action = praxis", where praxis refers to informed, committed action accompanied by reflection and action.

\section{The Media as a "Stakeholder" in Curriculum Design}

The media offered ways of enabling reflection through a broader engagement, connecting researchers with the information in the public space, thereby enabling the collaboration of broad-based stakeholder opinions that might inform curriculum design.

The curriculum policies of Unisa (University of South Africa) 2011, 2013) require that a range of stakeholders be consulted during the curriculum design process, including students in a related or similar qualification, relevant industry stakeholders, current job or career incumbents, representatives of the communities in which the graduates will work, and peer reviewers. In addition, these policies (Unisa (University of South Africa) 2011, 2013) require curriculum designers to respond to the following questions during the process of curriculum development which require broad consultation:

- Is the curriculum designed in such a manner that students become independent, resilient and caring citizens who are able to fulfil and serve in multiple roles in their immediate and future local, national and global communities?

- Does a study course include a variety of resources such as online resources, transdisciplinary sources and community resources?

We argue that broader stakeholder representation needs to be involved and that the media provides an expanded scope for this engagement. Schoeman and Mabunda (2012) in fact refer to the need to explore the interplay between individual student teachers and contextual variables that shape their learning and practice. This, they argue, is necessary for encouraging teachers' awareness of and building their personal and socio-professional identities. They thus see the curriculum as relying on a dynamic interplay of theory and praxis within critically reflective contexts and a broader engagement as providing the foundations for this to be realized. In a follow-up study, McIntyre-Mills et al. (2014) explore the impact of some of the Unisa curriculum design strategies and the value of the various stakeholders. Many of the themes raised as significant in the process of their curriculum design strategy resonate with the newspaper themes reported on in the current study. 


\section{Thematic Representations of Education}

We regarded the articles under review as one component of active citizenry in the public sphere in which the media is used as a vehicle for political expression and for highlighting areas of schooling that need political attention. The newspaper articles we have selected for analysis depict the situation and context of schools, highlighting the varied learning situations, contexts and environments of education in a range of schools and communities. They draw attention to the complex and differentiated nature of the South African society and highlight the diverse challenges faced by children in schools and the communities. They refer extensively to situations that depict the lingering effects of apartheid and problems with surrounding inclusivity and also problems of violence in various forms.

With the aim of the article being on the inclusion of the voices of civil society through the media, the authors focused on the role of the newspaper articles resonating with the kinds of situational context referred to in the MRTEQ, and signalling areas of concern that should be foregrounded in initial teacher development programmes. ${ }^{3}$ We recognize that what is considered newsworthy had implications for the curriculum which we, through our roles as academics in the College of Education at Unisa, could use in informing the practice of a large proportion of South African teachers. In this way we can give rise to a situated awareness, changes in teaching practices and also activating changes in policy.

Although the article was intended to show the trends in the media reporting and consequently highlighting themes of policy and practice, the emergence of the COVID19 pandemic brought about a new trajectory necessitating a differentiation between the media representations before the onset of the COVID-19 pandemic and contrasting these with the subsequent pandemic period, during which the narrative of newspaper articles on education focused on the need to plan for the lockdown, the consequential closure of schools, compensatory remote schooling and the problems associated with the reopening of schools. By differentiating between the articles as being pre-COVID-19 and during COVID-19, we were able to clearly show the different trends that emerged.

Coe and Kuttner (2018), in their analysis of media spanning some 35 years, describe the themes as shown in Table 1 that can be used to categorize the range of topics covered in the media.

\section{Aim of the Study}

This study aimed to explore the newspaper coverage of South African schooling to determine dominant themes or categories which may have a bearing on teacher development in relation to the contextual or situational knowledge that would be likely to frame the other forms of knowledge as defined in the MRTEQ, and which might be

\footnotetext{
${ }^{3}$ This study resonates with and enriches the stakeholder consultations already conducted with teachers, school principals and academics from education faculties in other universities as part of the process of developing the curriculum for the training of educators. We contend that the newspaper articles depict the broad-based views of communities, NGOs (such as the Education Labour Relations Council, Section 27, and other advocacy groups), teacher unions and parents about the issues of schooling. These stakeholders are seldom engaged in the design of curricula.
} 
Table 1 Typology of media themes on education

\begin{tabular}{|c|c|}
\hline Themes & Description \\
\hline $\begin{array}{l}\text { Teaching and } \\
\text { learning }\end{array}$ & $\begin{array}{l}\text { This category refers to topics related to what is taught and learned in schools, the way in } \\
\text { which it is taught and learned, why it is taught, and the efforts to measure or set } \\
\text { standards for this type of learning. This category is most directly related to what } \\
\text { Elmore (2004) calls the "instructional core" - the interaction between educators and } \\
\text { learners in the presence of content. }\end{array}$ \\
\hline $\begin{array}{c}\text { Structures of } \\
\text { schooling }\end{array}$ & $\begin{array}{l}\text { This category includes topics related to the way in which schools are governed; the way } \\
\text { in which educators are recruited, hired, supported, and organized in relation to the } \\
\text { various stakeholders in education. In South Africa, this will include the role of school } \\
\text { governing bodies and the teacher trade unions among the relevant stakeholders. }\end{array}$ \\
\hline $\begin{array}{l}\text { Climate, health, and } \\
\text { safety }\end{array}$ & $\begin{array}{l}\text { This category relates to the social, emotional, physical, and spiritual needs of learners and } \\
\text { the way in which these needs are either supported or endangered in the school context. } \\
\text { In this category, the focus of the media will be on the negative social dynamics (in the } \\
\text { community around the school) such as substance abuse, unsafe sexual behaviours, } \\
\text { school violence, bullying, fears for learners' safety, rights, health, and well-being while } \\
\text { at school, and on the need to create school climates that foster learning and growth. }\end{array}$ \\
\hline Equity and diversity & $\begin{array}{l}\text { This category refers to the media coverage on the inequities and disparities of race, class } \\
\text { and gender in schools. Whereas the first category of "teaching and learning" focuses } \\
\text { on what is taught, this category speaks to who is taught and in which way. It refers to } \\
\text { disparities in the achievement of learning outcomes. This category could also overlap } \\
\text { conceptually with other categories and extends the problems bequeathed from the } \\
\text { legacy of apartheid in South Africa, matters of inequity, exclusion, and a result of the } \\
\text { legacy disparities in schooling infrastructure and resourcing. }\end{array}$ \\
\hline
\end{tabular}

drawn upon in teacher education programmes. This study was intended to hear voices of civil society and the views of broad-based stakeholders such as the NGOs active in education, community voices, parents and also the voices of the learners as reported through the media. We examined the news reports on basic education on the Government Communication and Information System (GCIS) site, analysing the news coverage about education matters and identifying dominant themes to explore the problems depicted by the media and the implications these might have for providing a framework for situational or contextual knowledge.

\section{Research questions}

1. To what extent did the English-medium South African printed news media focus on schooling?

2. What were the main themes?

3. In what way could the media representations foregrounded the teaching of the situational knowledge for teacher education?

4. In what way did the themes and trends differ before and during the COVID-19 pandemic?

\section{Methodology}

We gathered all the English newspaper articles on the GCIS site that were relevant to basic education from October 2018 to June 2020 and subjected the articles to various stages of content analysis to offer a classification of education topics that featured prominently. Bailey (1982:312) refers to content analysis as a "marvellous social alchemy that can turn words into numbers", suggesting that the goal of content 
analysis is to "take a verbal, non-quantitative document and transform it into quantitative data". In this sense, we relied on mixing the approaches when classifying and interpreting the news texts. Although the process of content analysis is generally perceived as a technique belonging to the realms of the "scientific" positivist research, and from this perspective is often criticized for involving subjective judgements (Abercrombie et al. 1984:52), we, however, negate this and argue that the interpretation of data does not generate "invalid" data, but rather allows the data to develop through the researchers' engagement with the text and personal interpretation in relation to the context. Hence we argue that our use of the method of content analysis is heavily steeped in a non-realist tradition in which validity is not measured in terms of the reflection of the "real" but in terms of the way in which (new) meanings can be extracted from the text (McKay 1990, 2018a).

Furthermore, we argue that the data-collection stage in the process of content analysis involves an interaction between the researcher and the text. While the definitions of content analysis often tend to overemphasize the quantification of data, we, in line with the body of mixed-methods research approaches (Johnson and Onwuegbuzie 2004; Johnson et al. 2007) recognize that both quantified and unquantified data have their legitimate place in contemporary social science, and may be used for reciprocal data enrichment in the same study. In accordance with this view, the approach of content analysis as used in this study took account of our own roles in interpretation and determined themes through our engagement with the texts. Once we identified the thematic categories, we attempted to categorize and use these to inform the action-oriented curriculum design.

\section{Content Analysis}

\section{Stage 1. Obtaining the articles}

The articles reviewed included news articles from all the national daily and weekly English newspapers in South Africa and also textual records on some radio sites. We used this type of news coverage noting that it had previously been classified by the GCIS as being of relevance to the basic education sector.

The articles on the GCIS site were further identified as being of relevance to the South African Council for Education (SACE) whose mission is to enhance and safeguard public confidence in the teaching profession. The SACE registers teachers who are deemed "fit to practice". As part of its Code of Professional Ethics (SACE n.d.), the SACE acknowledges its vocation, the ideals and conduct of the teaching profession in upholding human rights, the need for learners to realize their potentialities, exercising authority with compassion, refraining from any form of abuse, physical or psychological or improper physical contact with learners, refraining from courting or any form of sexual relationship with learners from any school, refraining from any form of sexual harassment (physical or otherwise), ensuring the safety learners, and not being negligent in performing professional duties. Since professional ethics and the social contexts of learners are paramount in teacher development, many of the news articles pertained to the educators' fitness for practice. 


\section{Stage 2. Reading and culling}

During this phase, we read through the articles identifying those that dealt with the problems in schooling and we focused on the contexts of each article. We selected a subset of 360 articles with the first 212 gathered from October 2018 to February 2020 and a further 148 articles that were gathered from March 2020 to June 2020.

\section{Stage 3. Sorting and refining}

We recognized that our own reading and perceptions guided what we classified as being a "problem" in the context or situation of schooling and that the narrative since the emergence of the COVID-19 pandemic changed - hence our separating the articles into pre-COVID-19 and during COVID-19 categories.

We read each of the articles independently, coding them by topic and writing down key statements alongside the headline on our respective sheets. The data were then organized on a spreadsheet according to the theme, and key statements were listed alongside the headline to identify the newspaper and the date of publication. Statements that were transcribed into the templates were used verbatim from the newspaper article. While we had preconceived ideas of the themes and were cognizant of the themes identified by other researchers referred to above, we allowed the themes to emerge from our engagement with the text. The categories were examined to identify themes and subthemes.

After our individual categorisation of the articles, we compared our spreadsheets. Since many of the articles seemed to overlap the categories, we agreed to count them as falling into two categories and therefore counted them twice. Where we did not concur, a debate ensued as we discussed the article and tried to justify the rationale underlying the category we ascribed to the articles. In most of the cases we agreed that the article could be defined as straddling two categories, eg racism and bulling. In seeking to understand the problems referred to in each of the representations, we referred to the literature to understand the way in which the contexts of the depictions and the constructs were dealt with, both theoretically and empirically.

Moreover, in analysing the newspaper articles, particularly in cases where we were uncertain of the way in which to categorize the article, we followed an innovative abductive approach listening to the intermingled voices (of learners, parents or teachers) through what the article was expressing and listened to our own individual voices as researchers against the backdrop of our understandings of the context (McKay 2018b). This enriched our reading and interpretation of the text and guided us in our determination of what could be incorporated into the design of the educator curriculum.

After reading the articles independently, sharing and agreeing on our classifications, we concluded with a list of themes. Fig. 1 shows the breakdown of the contents of the articles. Common topics covered in the news clippings on schooling as shown in Fig. 1 include sexual abuse, rape, violence, murder, bullying, racism, fraud, discipline (mainly corporal punishment), curriculum, vandalism, teachers, and school and related infrastructure.

Some of the articles contained themes on, for example, ways of improving teaching or solving the problem through various suggestions, and we considered these to be pertinent during the COVID-19 period and because curriculum matters and ways of reaching (and not reaching) learners remotely during the COVID-19 pandemic revealed the stark inequalities arising from the digital divide as a result of socio-economic disparities. 


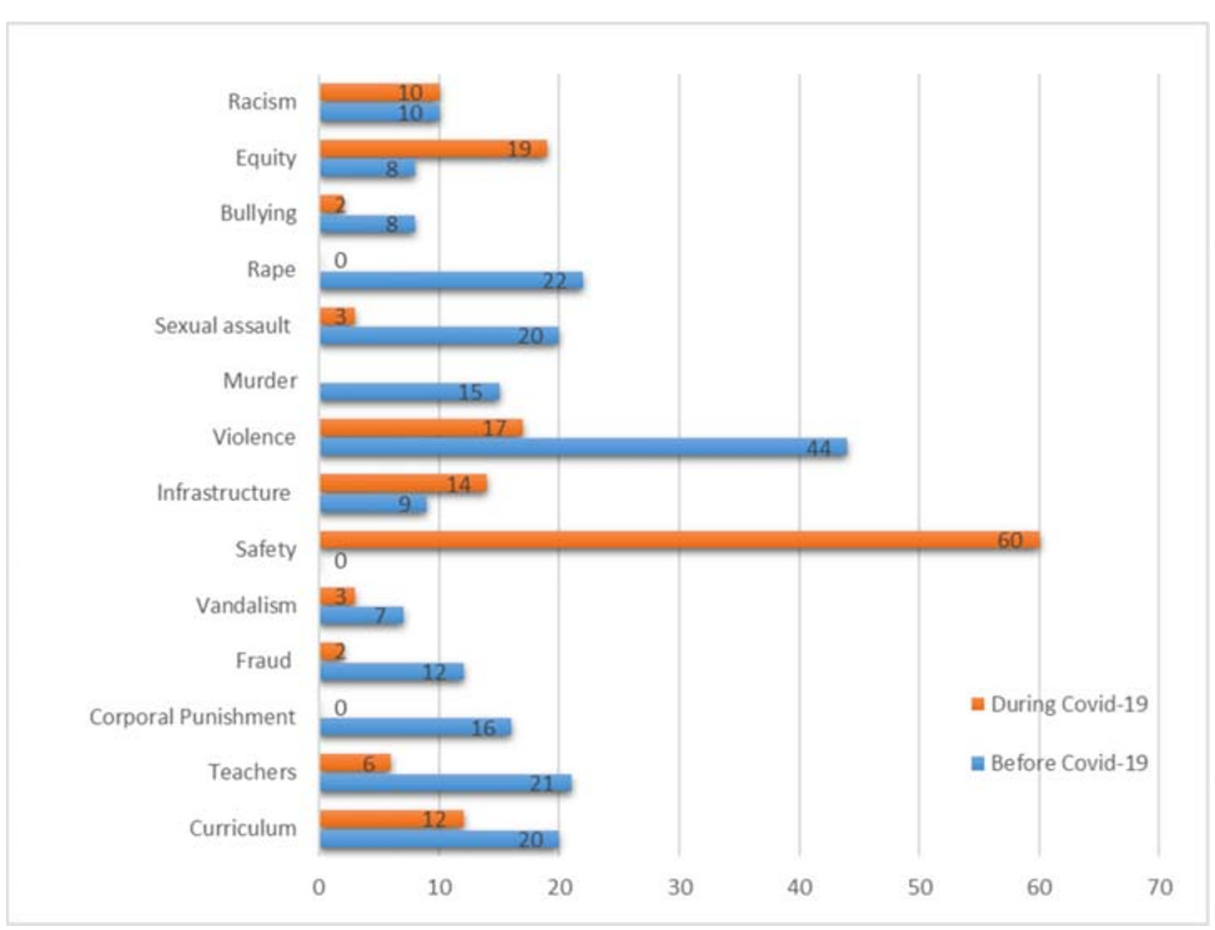

Fig. 1 Distribution of the topics of the news articles (actual numbers) before and during the COVID-19 pandemic

In the months from March 2020 to June 2020, the news media focused almost exclusively on the COVID-19 pandemic in relation to schooling. However, as shown in Fig. 1, the articles still straddled the same broad categories that were prominent in the previous 15 months, but with the media prioritizing school safety and school infrastructure. The sector contemplated closing the schools as a precursor to the national lockdown and after that, the preoccupation of the media during the lockdown was acutely with a focus on curriculum modifications and attempts to introduce remote modes of teaching. There was an increased focus on school safety as schools began to reopen (and close again) in line with government regulations.

We recognize the possibility that other researchers attempting the same exercise might identify other themes as being prominent.

\section{Analysis and Discussion of Findings}

As can be seen in Fig. 1, the same themes were reflected both pre-COVID-19 and during COVID-19. However, those incidences that were reported before the pandemic and which occurred on school premises, such as murder, rape and to some extent bullying, no longer took place in schools owing to the lockdown. Fig. 1 also shows the way in which school safety, which was virtually not reported on before the pandemic, was extremely prominent after the onset of the pandemic owing to the need for schools to adhere to the safety protocols on reopening with the majority of schools not being deemed ready. The situation of schools 
without water and sanitation facilities (running water and toilets) and adequate personal protective equipment (PPE) in addition to the growing number of infections in schools gave rise to a preponderance of news on the relationship between school safety and the inequalities in school infrastructure.

In order to organize the dominant themes, we further classified them as subsets of the categories referred to above by Coe and Kuttner's (2018) analysis of media which offers broad categorisation to organize the range of topics determined across the South African newspapers (Table 2).

Figs 2 and 3 show the breakdown of the topic clusters by proportion. Fig. 2 shows the clusters before the onset of the pandemic and Fig. 3 shows the breakdown after the onset of the pandemic. As is indicated in Fig. 3, school climate, health and safety and school organization were prominent over the period of the pandemic while schools were preparing for closure and, and later for reopening. These are in contrast to the themes discerned before the pandemic which pertained to issues of teaching and learning, and problems associated with equity and diversity as shown in Fig. 2.

\section{Climate, Health, and Safety in Schools}

The category of climate, health and safety relates to the way in which the social, emotional, physical, and spiritual needs of learners are supported or endangered in the context of the school. The news articles in this category focus on the negative social dynamics in and around schooling, such as drug or substance abuse, unsafe sexual behaviours, school violence, bullying, and fears for learners' safety. The fears for learners' safety relate to unsafe school infrastructure, the infringements of children's rights, health and safety while at school or on route to school, and the need to create school climates that foster learning and growth. As shown in Fig. 1, the pre-COVID-19 articles refer extensively to bullying, school discipline,

Table 2 Clustering the news topics into four categories

\begin{tabular}{|llll}
\hline Theme & Topics & $\begin{array}{l}\text { Before } \\
\text { COVID-19 }\end{array}$ & $\begin{array}{l}\text { During } \\
\text { COVID-19 }\end{array}$ \\
\hline Climate, health, and safety & Safety & 0 & 60 \\
& Infrastructure & 9 & 14 \\
& Violence & 44 & 17 \\
& Murder & 15 & 0 \\
& Sexual assault & 20 & 3 \\
& Rape & 22 & 0 \\
& Bullying & 8 & 2 \\
\hline Equity and diversity & Equity & 8 & 19 \\
& Racism & 10 & 10 \\
\hline Teaching and learning & Teachers & 21 & 6 \\
& Curriculum & 20 & 12 \\
& Discipline & 16 & 0 \\
\hline School organization & Corporal punishment & 16 & 0 \\
& Fraud & 12 & 2 \\
& Vandalism & 7 & 3 \\
\hline
\end{tabular}




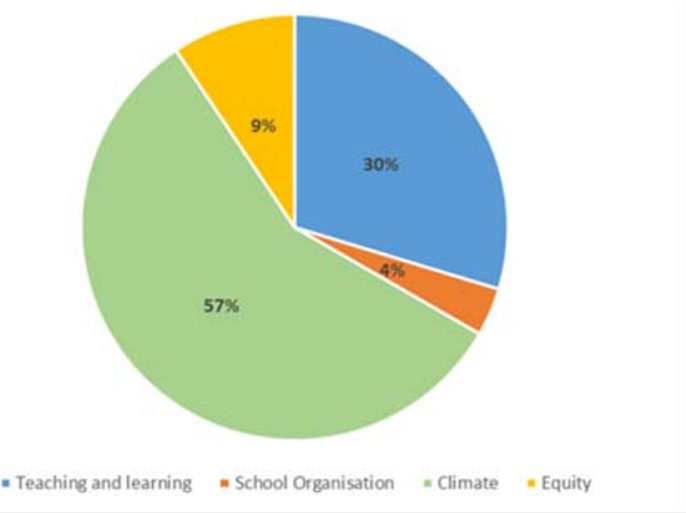

Fig. 2 Pre-COVID-19 news trends

infrastructural needs, violent assault, murder and rape. However, it was found that the coverage of articles since the onset of COVID-19 focused largely on health and safety. Issues regarding the need for water for handwashing, and adequate sanitation facilities were amplified as was the need for the supply of hand sanitizer and masks. These issues are a common problem in poorer and rural schools.

\section{School Violence, Sexual Abuse and Murder}

Violence and abuse are crimes that are reported frequently in South African. Crime and violence in schooling featured as the dominant theme in the media reports on schooling as shown in Fig. 1. The frequency of reports before the pandemic reflects a violent milieu of learners stabbing peers and teachers, learners being harassed or raped by teachers, or learners being bullied. In view of the high rate of coverage given to school violence, the articles pertaining to school violence were further subcategorized to facilitate a more nuanced understanding.

Discussions about causes and possible solutions for the high levels of violence plaguing the primary and secondary schools reveal society's heightened awareness of the prevalence of school violence.

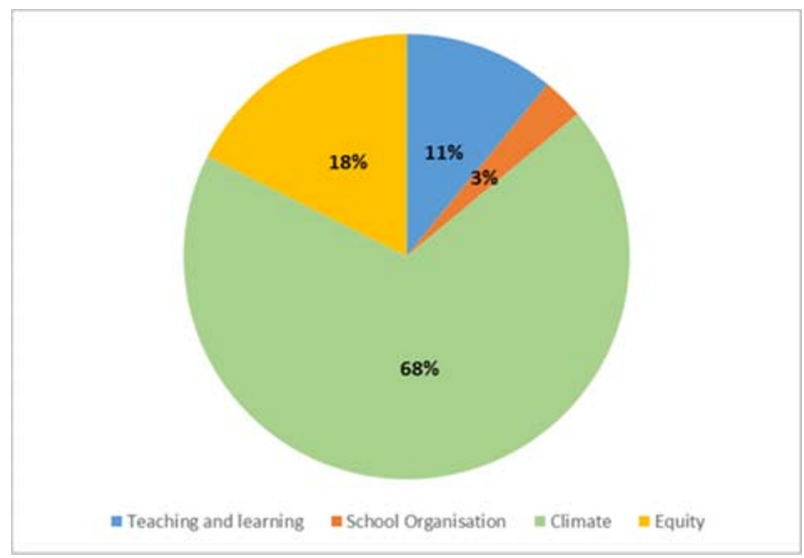

Fig. 3 During COVID-19 news trends 
Some articles blamed parents, peer pressure, political leaders, society in general, violent television programmes, and the spread of hatred and brutality through social media. Some articles suggested the provision of firearms to teachers as a solution (African News Agency 2019).

The spate of attacks in schools in which teachers, learners and security guards were killed on the school grounds was communicated in a post on Facebook giving rise to coverage in the daily newspapers. An article in the Daily News (2019c) reported on the KwaZulu-Natal Provincial Government's launch of a campaign on school safety and the training and deployment of thousands of volunteers to guard schools in the province, "We are taking practical measures to make schools safer. We cannot stand by and watch schools being turned into war zones. .. we will also take harsh disciplinary measures to protect our children in all places of learning" (Daily News 2019c).

As shown in Figs. 1 and 2, pre-COVID-19 cases of sexual incidences were common, and news articles referred to examples such as the high school principal who was to appear before the disciplinary committee of the provincial department of education for failing to take action against teachers at his school who were accused of sexual assault. The investigation was triggered by a video which circulated online showing learners reporting that some male teachers were asking for sexual favours and often fondled them during class lessons (Sowetan 2019c).

The Sowetan (2019d) reported on a teacher who was arrested for exchanging pornographic material with a 14-year-old learner with whom he was allegedly having a relationship (Sowetan 2019d), and the Cape Argus (2019) reported that a deputy principal of a primary school was suspended following allegations that he molested several grade 7 girls.

An article reports that the Department of Basic Education had dismissed 32 teachers in the previous year for various misconduct charges, including rape. Teachers preying on learners were among the more than 600 cases being investigated. The SACE, in its annual report tabled in Parliament, indicated that it had investigated a total of 633 cases against teachers, and that 93 of these cases were for the rape and sexual assault of children at schools. It added that out of 101 disciplinary cases, 67 teachers were found guilty, 11 were found not guilty and 23 cases had been withdrawn (SACE (South African Council for Education) 2019).

In response to these kinds of incidence, the SACE proposed to change its practice of registering teachers once-off, which effectively gave them a license to teach for life, and referred to its intention to introduce a system that requires teachers to re-register every three years. The large number of sexual assault cases led the SACE to requiring that all new teachers and students enrolling at a university for a teacher qualification produce a police clearance certificate (Daily News 2019a). This initiative has been met with cautious optimism by unions and school governing bodies (SGBs), contending that the SACE should rather focus on introducing a programme that will provide training for teachers' conduct (Staff Reporter 2018).

Although the number of school-based sexual abuse cases was obviously reduced during the lockdown, the media carried a number of sexual abuse cases after the onset of the pandemic showing an increase in gender-based violence and teen pregnancies as children were left unsupervised in their homes. One of the cases involving a schoolgirl was reported on in the Cape Times (2020c). The victim's classmates demonstrated at school as the 25-year-old man accused of her murder confessed to the crime in the local court four days after the 17-yearold's body was found. 


\section{Violence against Teachers}

Although much of the violence was perpetrated against learners, the violence against educators also received coverage in the newspapers. The Daily News (2019b) reported that a teacher at a high school had laid a charge of assault against a 20 -year-old learner after a video of the learner punching him went viral on social media. The video shows a group of learners intervening to stop the attack. The teacher who suffered an eye injury alleged that this was not his first assault at the school. "I have been assaulted many times at the school. I reported the incidents to the principal and the deputy principal before. I think this job is not safe for me," he said.

Another article reported on a learner who was filmed throwing a brick at a teacher. The video doing the rounds on social media shows the teacher running from the learner and then falling to the ground as the learner kicked him (TimesLIVE 2018d).

A 24-year-old teacher was stabbed with a butcher knife by a learner at a secondary school. The teachers then reported that they felt they were under siege and expected government to take action against the violence, complaining that violence is being institutionalized in schools (GCIS (Government Communication and Information System) 2018).

Given the spate of violence perpetrated against teachers, the City Press (2019) reported that young South African, highly qualified teachers seek better working conditions, improved salaries and well-resourced schools overseas. "Teaching conditions in South Africa are not conducive. Working in the schools, especially township schools, you go there at your own risk every day because we never know what will happen. .. a day at work as a teacher could possibly be your last. Those are some of the things that drive teachers away from the career and the country."

\section{Incidents of School Violence Perpetrated from outside of the School}

The media reports also depict the way in which violent incidents were perpetrated on scholars and teachers by criminals outside of the school leaving staff and learners very vulnerable. The high incidence of violence perpetrated outside of the school draws attention to the need for the training of SGBs that need to focus more broadly on the interaction of the school and the community.

In one such incident, a 12-year-old grade 6 girl died after being shot outside a primary school. The girl was the victim of a stray bullet from a drive-by shooting. According to the police spokesperson, another child's parents had come to pick up their child and saw a group of men in a minibus driving by and firing shots at them (News24 2019).

One of the newspaper articles reported on a video showing four men walking around a classroom after breaking into the school, looking into a safe while others searched for items of value, in full view of the school's CCTV camera (Citizen 2019).

\section{Bullying}

Bullying in schools received significant coverage in the news media. The Department of Basic Education actively discourages all forms of violence in schools including bullying, which is often violent, and recognizes the problems associated with e-bullying via the social networks and cellphone SMSs. Some schools have begun to use a multipronged approach involving the school, its teachers (who in some cases are alleged to be the bully), parents (of both the victim and the bully), and also the community. 
The Minister for Basic Education revealed there were 1345 violent hotspots in the country where "bullying is the most common form of violence in schools and often occurs between learners. School violence most often occurs on school premises, but it also takes place on the way to and from school." She also reported on the increase of cyber bullying, using online and mobile devices (Sunday Independent 2019).

With cellphones being ubiquitous, an article titled "Violence Institutionalized" reports on the school violence which is now visible as these attacks are filmed on cellphones and shared on social media platforms. This article reports on a video shared on Facebook that shows a grade 4 learner being kicked, punched and throttled by older girls. It refers to incidents involving children being choked, hit with objects or stabbed with a pencil and other forms of abuse. Another video showed a 13-vear-old boy being attacked outside the school toilets and then pinned to the ground and punched his head by a fellow learner (GCIS (Government Communication and Information System) 2018).

Often bullying is not only perpetrated by peers but also by teachers. A teenager who took her own life after she was allegedly bullied by her maths teacher for months left a suicide note. In her letter dated 16 September 2019, the teenager describes how unbearable her life had become. "I mostly fear going to my maths class. I am afraid of what my maths teacher will say or do to me to make me hate myself more than I already do. She enjoys embarrassing and humiliating me in front of my classmates." The teenager also stated that she was afraid to ask questions in class and felt sad most of the time (Sowetan 2019a).

\section{Substance Abuse}

Drugs and substance abuse is a known problem in South African schools. Although substance abuse did not receive prominence in the media, the relatively few articles reporting substance abuse nevertheless give direction for the development of situational knowledge for teacher education. One of the articles focused on a video showing seven high school learners, wearing their school uniforms, and holding an apple with a dagga joint (cannabis cigarette) stuck in the top (TimesLIVE 2018c).

One of South Africa's most expensive and exclusive schools also had drug scandal which resulted in the suspension of two learners with several others allegedly implicated in buying and selling dagga. The school offered "amnesty" to those who confessed their involvement (Mercury 2019).

\section{Racially Inspired Incidences}

As shown in Fig. 1, articles dealing with racism were published both before and after the onset of the COVID-19 pandemic.

A number of newspapers reported on the race row that ensued when an SGB constructively dismissed its first black teacher and certain parents called for the SGB to resign (TimesLIVE 2018b). Other racial reports included references to anti-Semitism with a grade 12 learner at a Jewish school reporting that she received an antiSemitic voice note from a learner from another school. Among other offensive statements, the boy is heard saying "... you should have died in the Holocaust" (Mercury 2018). 
Another report describes the way in which a prestigious private school came under fire for suggesting that an underprivileged black girl would "not fit in" after a donor offered to pay the child's fees for all 12 years of her schooling. Among the concerns cited in an email to the donors by the school was that "friendships at school often result in play dates, which can also become tricky because of the distance in travel, and result in a child feeling isolated and excluded" (Cape Times 2018). Some of the newspapers covered the story of angry "coloured" parents who prevented seven African teachers from entering the school premises (Sowetan 2019b). There were many reports of teachers who were racist and an article reports that a teacher was placed on suspension for using the K-word ${ }^{4}$ while teaching a class (TimesLIVE 2018a).

Notwithstanding the COVID-19 lockdown, reports on school racism persisted while the schools were closed. Many of the newspapers covered reports on racism in private or formerly white schools. The reports coincided with the \#BlackLivesMatter movement and referred to learners' testimonies of racism at school that were made public on the social media. The social media reports on racial discrimination gave rise to a formation called "Un-Silenced" comprising 200 past and present learners formed in response to the social media reports of racial discrimination at the school. Un-Silenced issued a letter to the school and the Old Girls Guild, detailing some of the inequalities they faced at the school (Daily Dispatch 2020a).

The inequalities included black learners not being allowed to practise their African customs or speak their mother tongue, being berated for speaking "loudly", and receiving disproportionate punishment in comparison to their white peers. Learners indicated that "we had to be grateful that we were allowed to be there", reporting a hostile experience requiring them to "erase all traces of our Africanness" (Herald 2020) and racist treatment at the hands of white teachers and white learners in white schools since the end of apartheid (Business Day 2020).

Also in the wake of the Black Lives Matter movement, The Witness (2020) in an article "Racism furore engulfs KZN's top private schools" related that a social media account laid bare the experiences of black African learners at some private schools at the hands of staff and learners. The storm started with an anti-racism account "yousilenceweamplify" created on Instagram and drew attention to the painful media accounts by current and former learners at these formerly white enclaves.

Inspired by the death of George Floyd, many young people shared their high school experiences on the social media, detailing the way in which they were subjected to injustices and prejudice in some traditionally white schools. "My first racial encounter at the school was in grade 8 when a girl told me. .. I remind her of her domestic and the guy that does the garden at her home. I was later told that black people behave like baboons. I filed a complaint to the school's authorities but the perpetrator was [barely punished]" (Herald 2020).

The Sowetan (2020b) reported that a white teacher at a private school had threatened to "kneel on the necks of pupils who did not do their work". The statement, a reference to the killing of George Floyd in the United States was publicized and the teacher was dismissed.

Following on these articles, the Citizen (2020) reported that the provincial department of education was to start a conversation about reconciliation and transformation, as it investigated the allegations of embedded racism in private and former white schools based on the social media reports of alleged institutional racism.

\footnotetext{
${ }^{4}$ The K-word is a pejorative racist slur against black Africans. The derogatory term was synonymous with the apartheid system. Its use is regarded as crimen injuria under South African law which may be defined to be the act of unlawfully, intentionally and seriously impairing the dignity of another person.
} 


\section{Safety at Schools during the COVID-19 Pandemic}

As shown in Fig. 1, during the COVID-19 pandemic, the issues of school safety featured as a prominent theme.

The media reported on teachers and learners resisting the proposed return to school. The Pretoria News (2020a) referred to the court proceedings of the official opposition party, challenging the decision that certain grades returned to school as being a "raging fire" during the time when saving lives remained a priority. Similarly, the Daily Dispatch (2020b) berated the Department of Basic Education stating that it was impossible for poor schools to adhere to social distancing because of the high learner:teacher ratios. The news articles criticized the plan of having learners attend school on alternative days, saying that the decision was being made in response to inadequate classroom facilities in schools in poorer communities and condemning government because the mud schools built in 1985 were falling apart (Daily Dispatch 2020c). In response, the Congress of South African Students (COSAS) threatened to close all schools to ensure the safety of learners (Cape Times 2020b). COSAS furthermore accused the Minister of Education of racism for suggesting that it is better for poor black children to be in school during the pandemic because of their "deplorable" home conditions. It argued that inadequate facilities made social distancing impossible and drew attention to the way in which the apartheid legacy impacted on poor communities. The Pretoria News (2020b) reported that an education activist group went to court to enforce the Department of Basic Education to continue its nutrition programme and to provide meals while the schools were in lockdown since this was often the only meal children received each school day.

Many schools chose to defy the national regulations: The Star (2020) reported on the decisions made by SGBs to close the schools as teachers tested positive for COVID-19. The Witness (2020) reported that the schools sent letters to parents indicating that as a precautionary measure, schools would be closed, and advised parents to monitor their children for symptoms, saying 'it is in the best interest of your child's and family's safety to keep your child at home until further notice". The Sowetan (2020c) reported that COVID-19 affected large numbers of schools. It reported on the continuity plans for e-learning and distance learning options, recognising that this was heavily contingent on socio-economic factors impacting on learners' access to data and devices and the teachers' ability to teach online challenges highlighted by Mabunda (2010) which still persist.

The Daily Dispatch (2020b) reported that inequalities in South Africa meant that some learners could use Zoom or Microsoft Teams for their classes, while other learners wondered where their next meal would come from because millions of children who previously benefitted from school feeding schemes that ceased during the lockdown. It argued, moreover, that online schooling had not been possible for $80 \%$ of South Africa's learners because teachers and learners do not have adequate tools, thus exacerbating inequalities as poor children lagged further behind. As one news articles pointed out, COVID-19 exposed "what was broken" and had not been dealt with. It exposed the "rickety health system may be pushed to the brink" and that "the South African public education system leaves a great deal to be desired" (Pretoria News 2020a).

The Daily Dispatch (2020d) underscored that on the eve of reopening schools, the Department was woefully unprepared with more than 100 schools in one province was unable to reopen because the schools did not have adequate sanitation facilities and had either mobile toilets which were not maintained and cleaned regularly or latrines (Cape Times 2020a). The Sowetan (2020a) reported that at one school, "parents wrangled with a security guard for the 
keys to the gate during a protest over lack of screening, sanitisers, soap and water at a school. .. saying this put their children's life at risk of contracting coronavirus. .. After we closed the school, the circuit manager came and told us that they have hired people to clean and screen pupils, teachers and other staff."

\section{Conclusion and Recommendations}

What is clear from the analysis of the media is that during the period under study, there were no positive news articles. The topics high on the agenda pertained to health and safety matters both before and after the onset of COVID-19 with safety from violence, sexual violence and safety from COVID-19 being the most prominent incidences reported on. School curriculum matters were not covered apart from the makeshift measures proposed as an attempt to ensure that teaching and learning continued during the pandemic.

The recommendations that emerged from this analysis refer to the need for contextual matters to be foregrounded in the curricula of educators. Teachers need to be aware of the negative social dynamics in and around schooling with regard to sexual behaviours, school violence, bullying, unsafe school infrastructure, the infringements of children's rights, health and safety, and the need to create school climates that foster learning and growth. However, as shown in Fig. 1, teachers are not vindicated when it comes to bullying, school discipline and sexual violations. Clearly, teacher ethics as required by the SACE and a deep understanding of Ubuntu are issues that need to be taken on board in teacher education curricula.

Health and safety in the school community is a perennial problem, and the residual effects of apartheid are found in poorer schools in which basic needs such as water and sanitation facilities are prevalent.

Dealing with violence against educators is highlighted as a matter that needs attention at the level of government but is also an issue that teachers need to be aware of and be able to mitigate. Unesco (United Nations Educational, Scientific, and Cultural Organization) (2017) has published a school safety manual with tools that would be usefully drawn upon for teacher curricula.

In addition, the findings of this study have implications for community members, SGBs, learners and specifically the Representative Councils of Learners who need to be equipped and empowered to identify and mitigate various forms of violence, knowing where and how to report and apprehend these. (We have discussed the implications of the findings in a separate article in which we explore possible interventions from a community and learner point of view.)

It is also essential for teachers to understand the way in which the socio-economic inequalities play themselves out in the context of schooling with children facing poverty, hunger, and inadequate health services. What was clear about the COVID-19 situation was that South Africa did not have a "plan B" to fall back on to ensure that teaching and learning could continue. Although this was heavily contingent on socio-economic factors including the access to data and devices, teachers need to have a "disaster awareness", to be able to think about "what if?" situations and a deeper understanding of distance and e-learning pedagogies.

We believe that one of the limitations of this study is that it was restricted to only the mainstream English media and that it did not explore news media published in the African languages which could have given a broader picture of the context of the themes discerned. Notwithstanding these limitations, this study provides school issues that are presented by the 
majority of the media (since the news coverage in the other official languages is relatively small). Our active engagement with the media as an extra way of exploring the challenges in schooling has offered a complementary way of refining the information we gained from the stakeholder consultations required by the university with the news media articulating the voices of a broader and varied stakeholder base from across the country. We argue that a participatory active research approach as conducted in this study offers an alternative research approach under COVID-19 disaster circumstances. This active engagement offered expanded directions for what can be included in teacher education curricular when the focus on situational knowledge is relevant.

It can be further concluded that education discourses in the media are intentionally created by certain stakeholders with the aim of influencing and shaping the opinions of readers and justifying political decisions (Erss and Kalmus 2018). Teachers need to take more responsibility for the portrayal of education and school news, to shape the discourses and to counter the "deficit" and negative discourses. Engagement can "deterritorialize or reterritorialize" existing negative narratives of the professional inadequacy crisis. Countering with narratives that portray complexities in the teaching profession potentially embodies a first move in shifting public discourse about education onto both more nuanced and more productive territories (Ulmer 2016:49, 52). This study confirms Baroutsis's (2019:16) contention that there is scope for scholarship in education research to more actively focus on the excluded voices through engaging the media, but we argue that there is much to be done in dealing with the issues faced in schools by mediating change through the curriculum on offer for trainee and inservice educators.

Authors' Contributions N/A

Data Availability N/A

\title{
Compliance with Ethical Standards
}

\author{
Conflicts of Interest/Competing Interests N/A
}

Code Availability N/A

\section{References}

Abercrombie N, Hill S, Turner B (1984) The penguin dictionary of sociology. Penguin, Harmondsworth African News Agency (2019) Government, NGOs put focus on school safety. 27 August 2019

Bailey K (1982) Methods of social research. Collier Macmillan, London

Baroutsis A (2019) Mapping the field of education research and media. In: Baroutsis A, Riddle S, Thomson P (eds) Education research and the media: challenges and possibilities. Routledge, New York, pp 1-24

Business Day (2020) Rooting out systemic racism in our schools. 23 June 2020

Cape Argus (2019). Bonteheuwel school deputy principal suspended after allegedly molesting Gr. 7 girls. 20 September 2019

Cape Times (2018) Rustenburg girls' junior petition slating 'biased' reports questioned. 16 November 2018

Cape Times (2020a) History teacher quits around racism storm. 11 June 2020

Cape Times (2020b) Student body shuts schools for protection. 23June 2020

Cape Times (2020c) Femicide: Murdered Amahle remembered as 'big-hearted'. 24 June 2020

Citizen (2019) Brazen robbers break into Tembisa school. 19 November 2019

Citizen (2020) School racism investigated. 24 June 2020

City Press (2019). Underpaid teachers exposed to danger on the job are now leaving SA. 6 August 2019 
Coe K, Kuttner P (2018) Education coverage in television news: a typology and analysis of 35 years of topics. Aera Open 4:1-13. https://doi.org/10.1177/2332858417751694

Daily Dispatch (2020a) Unsilenced aims to open racism discussions at school. 19 June 2020

Daily Dispatch (2020b) No clear way for all schools to reopen. 22 June 2020

Daily Dispatch (2020c) Mud schools built in 1984 'falling apart', say parents. 22 June 2020

Daily Dispatch (2020d) School returns 200 positive tests. 24 June 2020

Daily News (2019a). Police clearance for all new teachers gets thumbs-up. 18 January 2019

Daily News (2019b). Durban pupil suspended after assaulting teacher in viral video. 7 June 2019

Daily News (2019c) School safety programme launched in KZN. 17 September 2019

DHET (Department of Higher Education and Training) (2015) Policy on the minimum requirements for teacher education qualifications, 2nd edn. Government Gazette, Pretoria

Elmore R (2004) School reform from the inside out: policy, practice, and performance. Harvard Education Press, Cambridge

Erss M, Kalmus V (2018) Discourses of teacher autonomy and the role of teachers in Estonian, Finnish and Bavarian teachers' newspapers in 1991-2010. Teach Teach Educ 76:95-105. https://doi.org/10.1016/j. tate.2018.08.003

GCIS (Government Communication and Information System) (2018) Violence institutionalised. 8-11 September 2018

Habermas J (1974) The public sphere: an encyclopaedia article (1964). New German Critique 3:49-55. https://doi.org/10.2307/487737

Herald (2020) Schools must act on racism. 22 June 2020

Johnson RB, Onwuegbuzie AJ (2004) Mixed methods research: a research paradigm whose time has come. Educ Res 33:14-26. https://doi.org/10.3102/0013189X033007014

Johnson RB, Onwuegbuzie AJ, Turner LA (2007) Toward a definition of mixed methods research. J Mixed Methods Res 1:112-133. https://doi.org/10.1177/1558689806298224

Kemmis S (2009) Action research as a practice-based practice. Educ Action Res 17(3):463-474. https://doi. org/10.1080/09650790903093284

Liu R, Lin P (2017) Changes in multicultural experience: action research on a service learning curriculum. Syst Pract Action Res 30:239-256. https://doi.org/10.1007/s11213-016-9395-2

Luckay M (2018) The re-design of a fourth year bachelor of education programme using the constructive alignment approach. Tuning J High Educ 6:143-167. https://doi.org/10.18543/tjhe-6(1)-2018pp143-167

Mabunda PL (2010) Information and communication technologies for teaching and learning: challenges and implications for ODL universities. Progressio 32(2):222-244

McIntyre-Mills J, Kedibone GM, Arko-Achemfuor A, Mabunda P, Njiro E (2014) Participatory approach to education: an action learning approach at the University of South Africa. Participatory Educ Res 1(2):106132. https://doi.org/10.17275/per.14.14.1.2

McKay V (1990) A sociological study of people's education in South Africa: A humanist evaluation. Thesis, University of South Africa

McKay V (2018a) Through the eye of a fly: action research as a support for the south African national literacy campaign. Syst Pract Action Res 31(4):375-393. https://doi.org/10.1007/s11213-017-9431-x

McKay V (2018b) Literacy, lifelong learning and sustainable development. Aust J Adult Learn 58:390-425

McKay VI, Romm NRA (2008) Active research towards the addressal of HIV/AIDS in the informal economy in Zambia: recognition of complicity in unfolding situations. Action Res 6(2):149-170. https://doi.org/10.1177 $/ 1476750307087050$

Mercury (2018) Teen anti-Semitism victim reaches out. 9 November 2018

Mercury (2019) Marijuana scandal at top KZN private school. 13 June 2019

Mockler N (2018) Discourses of teacher quality in the Australian print media 2014-2017: A corpus-assisted analysis. Discourse: Studies in the Cultural Politics of Education 1-17. https://doi.org/10.1080 /01596306.2018.1553849

News24 (2019) Katlehong schoolgirl, 12, killed by stray bullet in drive-by shooting. 19 September 2019

Pretoria News (2020a) It's time to embrace change. 11 June 2020

Pretoria News (2020b) Activists go to court over school meals. 23 June 2020

Rheingold H (2008) Using participatory media and public voice to encourage civic engagement. In: Bennett L (ed) Civic life online: learning how digital media can engage youth. MIT, Cambridge, pp 97-118. https://doi.org/10.1162/dmal.9780262524827.097

Rusznyak L (2015) Knowledge selection in initial teacher education programmes and its implications for curricular coherence J Educ 60

SACE (South African Council for Education ) (n.d.) Code of ethics https://www.sace.org.za/pages/the-code-ofprofessional-ethics. Accessed 24 September 2020

SACE (South African Council for Education) (2019) Annual report 2019. SACE, Pretoria 
Schoeman S, Mabunda PL (2012) Teaching practice and the personal and socio-professional development of prospective teachers. S Afr J Educ 32(3):240-254. https://doi.org/10.15700/saje.v32n3a581

Sowetan (2019a) Cruel teacher killed my girl. 14 January 2019

Sowetan (2019b) Teachers shut down Eldorado Park schools. 29 January 2019

Sowetan (2019c) Durban principal in hot water over 'predatory' teachers. 31 July 2019

Sowetan (2019d) Cellphone under teen's pillow leads to teacher's arrest for sexual grooming. 21 November 2019

Sowetan (2020a) Parents shut school over lack of hygiene, sanitation. 11 June 2020

Sowetan (2020b) Schools, no place to teach racism. 11 June 2020

Sowetan (2020c) Covid-19 hits more than 150 SA schools. 19 June 2020

Staff Reporter (2018) SADTU at odds with SACE over re-licensing of teacher. 24 October 2018

Sunday Independent (2019). Bullying. 1345 hot spots for school violence 15 September 2019

The Star (2020) Pandemic: School failed our children. 24 June 2020

The Witness (2020) Racism furore engulfs KZN's top private schools. 10 June 2020

TimesLIVE (2018a) Teacher union slams Durban 'k-word' teacher. 29 August 2018

TimesLIVE (2018b) Top cape school stands firm in the wake of public race row. 8 November 2018

TimesLIVE (2018c) Pupils face disciplinary action after 'dagga apple' video goes viral. 9 November 2018

TimesLIVE (2018d) 'I have been patient with him for a long time' pupil throws brick at teacher. 14 November 2018

Tsai H, Liu R (2019) Action study of community-based aesthetic education course design and practice for senior citizens. Syst Pract Action Res 33:137-147. https://doi.org/10.1007/s11213-019-09484-x

Ulmer JB (2016) Re-framing teacher evaluation discourse in the media: an analysis and narrative-based proposal. Discourse: Stud Cult Politics Educ 37:43-55. https://doi.org/10.1080/01596306.2014.921756

Unesco (United Nations Educational, Scientific, and Cultural Organization) (2017) School safety manual: tools for teachers. UNESCO International Institute for Capacity-Building in Africa. UNESCO-IICBA, Addis Ababa

Unisa (University of South Africa) (2011) Implementing the Unisa curriculum policy (implementation plan for the curriculum policy). Unisa, Pretoria

Unisa (University of South Africa) (2013) Framework for the implementation of a team approach to curriculum and learning development at Unisa. Unisa, Pretoria

Publisher's Note Springer Nature remains neutral with regard to jurisdictional claims in published maps and institutional affiliations. 